\title{
COMMUNICATION AND MANIPULATION STRATEGIES OF TRAVEL GUIDES PRESENTING CROATIA - A LINGUISTIC PERSPECTIVE
}

\author{
Brigita Bosnar-Valković \\ Suzana Jurin
}

https://doi.org/10.20867/tosee.05.33

\begin{abstract}
Purpose - It is amazing that in the age of IT, despite the availability of alternative promotional tools, such as e-brochures and websites, which are easily accessible, hard print travel guides still remain as popular as ever because they can act as a substitute for a product which cannot be physically seen or inspected prior to comsumption. Also, tour operators can hardly standardize their products and services due to many uncontrollable factors (e.g. the weather). To maximize their persuasive power, tourism guides are found to be loaded with hyperbolic language and glamorous images. The question we would like to answer is how far this classical structure and the accompanying communication strategies still meet the requirements of their users. Accordingly, the purpose of this research is to analyze the communication and manipulation strategies of travel guides and consequently to offer some suggestions in order to modernize them and make more effective.

Methodology - In our study, the travel guides are subject to a multimodal analysis which includes a qualitative analysis focused on the linguistic resources and communicative strategies adopted to promote Croatia. Text linguistic analysis provides data about the language of the selected texts of travel guides, mostly on its morphology, syntax and lexis which is of great importance for potential tourists to situate a virtual text within a cognitive frame.

A quantitative analysis (using Mediatoolkit) focused on the frequency and distribution of words in the texts provided further insight and additional value of the results gained by qualitative research. Finally, a sentiment analysis of the contents and of the general feelings of the selected travel guides texts, using open source tools, was performed.

Findings - This research will result in several outputs concerning the qualitative linguistics, quantitative and sentiment analysis of the selected texts (evaluative terms, positive, negative or neutral sentiments).

Contribution - The preliminary results of this research will open up opportunities for future research and practical implications of the results gained that could be implemented in the creation of modern travel guides evoking positive sentiments.
\end{abstract}

Keywords travel guides, linguistic appeal, qualitatve linguistic analysis, quantitative corpus analysis, sentiment analysis.

\section{INTRODUCTION}

From the perspective of the language of tourism, i.e. when the "language of tourism" was initially articulated, tourism formed part of the project, wherein its unilateral, monological discourse was framed within the parameters of social control (Dann 2012, 59). 
ToSEE - Tourism in Southern and Eastern Europe, Vol. 5, pp. 121-138, 2019

B. Bosnar-Valković, S. Jurin: COMMUNICATION AND MANIPULATION STRATEGIES OF ...

Despite the availability of alternative promotional tools, such as e-brochures and websites, which are easily accessible, hard print travel guides still remain as popular as ever because they can act as a substitute for a product which cannot be physically seen or inspected prior to comsumption. Also, tour operators can hardly standardize their products and services due to many uncontrollable factors (e.g. the weather). To maximize their persuasive power, tourism guides are found to be loaded with hyperbolic language and glamorous images.

Taking into account their persuasive power, the purpose of this research is to analyze the communication and manipulation strategies of travel guides presenting Dubrovnik. Dubrovnik has, namely, been chosen as a unique among world-class towns with its fascinating cultural, historical and art heritage, which makes it a highly popular tourist destination.

\section{TRAVEL GUIDES AND THEIR FEATURES}

Due to the intangible and heterogeneous nature of tourism products, travel brochures and guides have a distinctive function in that that they can act as "a substitute for a product which cannot be physically seen or inspected prior to purchase" (Holloway 2004, 17). Travel guides are an "on-trip" text genre because tourists read it when they are on holiday. Their function is descriptive and to give practical information; this is the most comprehensive genre and it is the only genre that may contain a negative expression or description. Guides are "real" books, longer than any other tourist text, and cover a wide variety of information. They provide historical and cultural insight into the destination and provide the reader with useful tips and practical advice. They are normally more subjective than general tourist texts (the role of the author is highly recognizable). In general, travel guides do not strictly belong to the promotional genre of tourism but rather to the informative one (they mainly provide information and descriptions).

Highlights and itineraries help tourists to tailor their trip to their personal needs and interests. Special emphasis is put on certain insider tips aimed at saving time and money and get around like a local, avoiding crowds and trouble spots. Closely related to them are honest reviews for all budgets - eating, sleeping, sightseeing, going out, shopping, hidden gems that some guidebooks might be missing. Cultural insights provide visitors with a richer, more rewarding travel experience - history, cuisine, natural environment, arts, architecture.

However, the language used in travel guides has the main function of constructing and guiding the tourist experience. Guidebooks, therefore, select the destination and provide information about it, but at the same time they shape the image of the destination, i.e. the reader can draw his own conclusion according to the author's opinions and linguistic choices.

The communicative intent is to provide tourists with the essential information for helping them decide what places to visit and which tour(s) to book. Therefore, successful travel guides must be both informative and persuasive, and they rely on various communication and visual techniques to achieve this aim. 
ToSEE - Tourism in Southern and Eastern Europe, Vol. 5, pp. 121-138, 2019

B. Bosnar-Valković, S. Jurin: COMMUNICATION AND MANIPULATION STRATEGIES OF ...

\section{CORPUS AND METHODOLOGY}

The linguistic and textual analysis was performed on the selected corpus of representative presentations on Dubrovnik, excerpted from the Lonely Planet and Eyewitness Travel Guide on Croatia.

This study takes into account Brinker's et al. classification of text genres and the textual analysis on three levels (Brinker et.al., 2014). Texts will be analyzed on the communicative pragmatic, thematic level of the content structure of the text, as well as the linguistic and stylistic level of travel guide texts on Dubrovnik.

At the communicative-pragmatic level the function of the text within the communication process i.e. the communicative intention of the sender (text producer) which is expressed and presented through conventional means to the text recipient, who in turn, decodes the content and recognizes the communicative intention of the sender.

\section{LINGUISTIC ANALYSIS OF TEXTUAL FEATURES OF TRAVEL GUIDES}

Travel guides are a text genre with mainly descriptive function focused on giving practical and objective information about a particular tourist destination. Pieces of information in travel guides are arranged as they appear in time and space. Tourists firstly find out where to stop, and then where to go and what to see there. Nilsson (2001), who explores nominal phrases in English travel guides, says that the basic feature of this text type is the density of information, which is very often achieved by using complex nominal phrases.

\subsection{Communicative features of travel guides}

The text-linguistic analysis of different travel guides shows that the travel guide is prevailing an assertive text type. The reasons for placing a travel guide in the assertive text type, subtypes informative, explicative and orientative texts, and concerning its persuasive form in some text examples or mainly text segments (e.g. description of a tourist destination, hotel description, restaurant description, calendar of events, city map, price list, timetable etc.), it also belongs to the directive text type, subtype instructive texts (Hoffmann 1998, 538):

1. The first communicator is the text producer (the author of the guide who is in most cases also a former tourist or traveller, so he writes from his own experince - from his personal perspective) who has given basic information about tourism destination, or has already lured the text recipient through directive and instructive statements. Both, the text producer and text recipient have access to basic information about the tourist destination, and the recipient confirms interest by reading the travel guide.

2. The primary purpose of a communication through a travel guide is to establish a binding relationship of the text recipient towards the text producer and vice versa; instructions, suggestions and explications set forth in the travel guide are expected to be met. 
ToSEE - Tourism in Southern and Eastern Europe, Vol. 5, pp. 121-138, 2019

B. Bosnar-Valković, S. Jurin: COMMUNICATION AND MANIPULATION STRATEGIES OF ...

3. The fundamental communication process of the travel guide is information and instruction, in some cases realization of given advices.

4. The communication situation using the travel guide is to set the arrival and consumption of the tourism destination.

5. The communication subject is receiving the most important information about the tourism destination.

\subsection{Text-linguistic analysis of travel guides}

Considering the above mentioned, a text linguistic analysis shows that the main text function of the text genre travel guide is to inform, explain, give orientation and direct text recipients towards or about a certain tourist destination. But besides this text function, the travel guide also contains text segments whose main text function is to promote a specific destination, which means that certain text segments can be classified as directive texts (advertisements, culinary recipes, etc.). According to Ling Ip $(2008,1)$ successful travel guides and brochures must be both informative and persuasive, and they rely heavily on the use of language and images to achieve this aim.

On the macrostructural level, text genre travel guide is functionally structured, clearly laid out and enriched with numerous images. The list of contents is followed by the explanations of used symbols and the introductory text. In their main part the travel guides usually provide general information on climate and prices and various useful tips which is followed by a description of the destination including geographical features, historical overview, description of sights, list of catering facilities and their short description ending up with a list of cultural events and other entertainment options, city map etc.

The performed analysis showed that at the macrostructural level this text genre is divided into two or more texts parts. The analyzed text part is further divided into three text segments, titled with Street-by-Street Dubrovnik and Exploring Dubrovnik.

The first text segment entitled Street-by-Street Dubrovnik starts with the introductory part with basic information about Dubrovnik's history and art heritage. It is further subdivided into subsegments including the Star Sights with Cathedral Treasury, Dominican Monastery, Rector's Palace and Sponza Palace. In the introductory part providing basic information about Dubrovnik complex sentences mainly in past tense prevail, e.g.:

Set in the limpid waters of the Adriatic, Dubrovnik had been, until war broke in 1991, one of the top international tourist destinations of Dalmatia, renowned for the beauty of its monuments, its magnificent walls and welcoming atmosphere.

The introductory part is underlined with strong adjectives sometimes in superlative form to express the worth of visiting Dubrovnik, e.g.: ... one of the top international tourist destinations of Dalmatia, magnificent, welcoming... 
ToSEE - Tourism in Southern and Eastern Europe, Vol. 5, pp. 121-138, 2019

B. Bosnar-Valković, S. Jurin: COMMUNICATION AND MANIPULATION STRATEGIES OF ...

The textual subsegment Star Sights contains short sentences, as well as complex sentences, very frequent relative clauses which provide additional explanation, e.g.:

Rector's Palace - The highest level of city government met here. The rector lived here during his period of office, which was limited to one month.

The analyzed text segment is multimodal (Matheson, 2005). Multimodality is clearly evident in printed advertisements, a typical written genre where "signs", such as language, images, graphics and typography, are combined "in an integrated whole" (van Leeuwen 2004, 10).

It is very well known that images play an important role in convincing people to visit a certain place. They act as stimuli to the readers' minds. Similar to the findings from the textual analysis, it is observed that in tourism discourse images are also highly selective and emphasize only the positive aspects. It is sometimes questionable whether the images in travel brochures and guides are representatives of reality.

Collage is a prominent feature found in the images in travel guides and it was also found in the text on Star Sights in Dubrovnik. According to Gold $(1994,22)$, it is "perhaps the most distinctive feature of place promotional advertising". Gold (ibid.) points out that collage typically employs "three to six photographs of the place concerned along with a portion of descriptive text", which stands for "a visual summary of the different elements in the selling image". The collage in the analyzed sub-segment on Star Sights in Dubrovnik employs six photographs scattered around the drawn city map of the very center of Dubrovnik with highlighted streets. The collage also contains a portion of a descriptive text.

The sub-segment titled Exploring Dubrovnik consists of short descriptions of the other numerous sights in Dubrovnik - sixteen of them. This part is introduced through a short informative text on Dubrovnik as a UNESCO's world heritage site that was exposed to a merciless destruction by Yugoslav troops during the Homeland war.

After this informative introduction short descriptions of very many Dubrovnik's sights follow. On the language stylistic level these short descriptions of the sights employ the following:

1. many time adverbs combined with the numerical data (...in the 10th century...; ... from $1537 \ldots$; ... designed in $1538 \ldots$; ... it was built in $1438-44 \ldots)$;

2. adjectives suggesting beauty and uniqueness of a sight (The wall offer splendid views....; ... an extraordinary collection of ...);

3. adjectives in superlative (This is the most visited of the walls....; ...on of the bestknown monuments...);

4. the passive voice - mainly in past tense (It was designed by ; The city's art treasures were brought here .... ; ... is known as Stradun ...);

5. numerical data referring to the important time period - either century or a year (...from 1537...; ... with modifications in the 13th century...; ... in use since $1317 \ldots$ ; ... from the 16th-18th centuries...) or referring to the size or dimensions of the sight (Those facing inland are up to $6 \mathrm{~m}(20 \mathrm{ft})$ wide...; The walls and ramparts are $1,940 \mathrm{~m}(6,363 \mathrm{ft})$ long and reach a height of $25 \mathrm{~m}(82 \mathrm{ft}) \ldots)$. 
ToSEE - Tourism in Southern and Eastern Europe, Vol. 5, pp. 121-138, 2019

B. Bosnar-Valković, S. Jurin: COMMUNICATION AND MANIPULATION STRATEGIES OF ...

Here, like in the previous section the collage employs the photos of Dubrovnik's sights and Dubrovnik town centre city map with highlighted sights, once again accompanied by descriptive text.

\section{QUANTITATIVE ANALYSIS}

Corpus linguistics relies on a strong quantitative element as its constituent part. In this paper the quantitative analysis was performed to identify the frequency and distribution of words and patterns in the texts, in order to provide further insights and integrate quantitative results with the information value provided by the qualitative analysis.

\subsection{Methodology}

The aim of the performed quantitative analysis was to identify the frequency and distribution of words and patterns in the texts, by using AntConc Corpus Tool, version 3.4.4.0, a free software tool for text annotation and analysis

(http://www.laurenceanthony.net/software/antconc/).

The free software tool is used in this study in order to create word lists, frequency lists, and concordances that will provide useful insights into the textual elements that build social significance of the analyzed guides. The implementation of the AntConc Corpus Tool, version 3.4.4.0 also demonstrates how corpus linguistics and corpus methods can contribute to the linguistic analysis.

The textual corpora on Dubrovnik from both travel guides Lonely Planet and Eyewitness were scanned and downloaded. The texts on Dubrovnik from the Lonely Planet Guide are composed of approximately 23,000 words and from the Eyewitness Travel Guide of 15,000 words, so that a corpus amounting to 38,000 words was analyzed.

The second step was to pre-process the text corpora, which means eliminating 'stopwords', such as the, $a$, an, and, etc., to enable a lexical analysis on content-driven terms. Wordlists were then generated, i.e., a list of words in order of frequency of appearance, and an analysis of the concordance lines i.e., the words which are used before and after the search item, was also carried out in order to identify and investigate words in the textual context. Besides identifying the frequency and distribution of words and patterns in the texts, interesting relevant insights into the structure and usage of a language are obtained.

\subsection{Results of the quantitative linguistic analysis}

The analysis shows that the texts in the analyzed corpus are of mainly descriptive nature and the verbs that appear at the top of the frequency list in both analyzed guides have a typically static meaning (is, are, has, can). Stative verbs can be seen and compared in the table that follows (Bait et al. 2018, 7). 
ToSEE - Tourism in Southern and Eastern Europe, Vol. 5, pp. 121-138, 2019

B. Bosnar-Valković, S. Jurin: COMMUNICATION AND MANIPULATION STRATEGIES OF ...

\section{Table 1: Frequency of verbs with static meaning}

\begin{tabular}{|l|l|l|}
\hline Rank & Lema & Hits \\
\hline 1 & is & 614 \\
\hline 2 & are & 252 \\
\hline 12 & has & 141 \\
\hline 14 & can & 129 \\
\hline 20 & have & 56 \\
\hline
\end{tabular}

In the analyzed corpus, the first example of a lexical verb indicating an action (offer) is found at rank 25, immediately followed by enjoy at rank 43 and located at rank 65.

\section{Table 2: Frequency of verbs indicating an action}

\begin{tabular}{|l|l|l|}
\hline Rank & Lema & Hits \\
\hline 25 & offer & 78 \\
\hline 43 & enjoy & 69 \\
\hline 65 & located & 51 \\
\hline 83 & look & 47 \\
\hline 110 & protected & 39 \\
\hline 132 & head & 35 \\
\hline 156 & built & 23 \\
\hline 183 & surrounded & 19 \\
\hline 192 & notice & 18 \\
\hline 214 & house & 16 \\
\hline
\end{tabular}

Table 2 provides the list of ten most frequent verbs used in the corpus and it shows that the verbal selection is focused on description of the sites of interest (as suggested by protected, house, surrounded, located, built) and encouraging tourists to take action (as suggested by the verbs enjoy, look, head,notice). The verbs encouraging tourists to take action are very often accompanied by the personal pronoun you aimed at tourists engagement and their interactivity, as shown in the following examples: ...you definitely can enjoy the nature and culture... or ... you can head up to the roof... or ... Regardless of whether you are visiting Dubrovnik for the first time .... etc.

Table 3: Concordance 1 - you with can and will

\begin{tabular}{|l|l|}
\hline CAN & WILL \\
\hline $\begin{array}{l}\text { you can get ready for an exciting day in } \\
\text { Montenegro }\end{array}$ & you will notice the finely carved capitals \\
\hline you can be a true taster & $\begin{array}{l}\text { you will get to see the capital of a } \\
\text { sophisticated republic }\end{array}$ \\
\hline you can enter the town from both sides & $\begin{array}{l}\text { to reach the nudist beach you will head left } \\
\text { from the ferry }\end{array}$ \\
\hline you can drive through the narrow streets & $\begin{array}{l}\text { you will find the perfect way to evoke the } \\
\text { glorious history }\end{array}$ \\
\hline $\begin{array}{l}\text { you can enjoy the endless shimmer of the } \\
\text { Adriatic }\end{array}$ & $\begin{array}{l}\text { you will feel close to a glittering jewel of the } \\
\text { Adriatic }\end{array}$ \\
\hline you can note that no one stays overnight & you will find Dubrovnik's glitziest restaurant \\
\hline you can visit a very cool design store & you will take the cable car up to Mt Srd \\
\hline
\end{tabular}


ToSEE - Tourism in Southern and Eastern Europe, Vol. 5, pp. 121-138, 2019

B. Bosnar-Valković, S. Jurin: COMMUNICATION AND MANIPULATION STRATEGIES OF ...

The examples in table 3 prove that the target consumer "you" is an explicit actor. „You“ in combination with the modal can exemplifies that the tourist is the subject as an active doer, and can transmits the idea of possibility, while the occurrences with will include the idea of possibility and certainty.

Table 4: Concordance 2 - you in subject and object position

\begin{tabular}{|l|l|}
\hline \multicolumn{1}{|c|}{ Subject position } & \multicolumn{1}{c|}{ Object position } \\
\hline You will then plunge into the azure sea & Dubrovnik offers you something unique \\
\hline $\begin{array}{l}\text { You will access the cloister and the museum } \\
\text { via the small passag }\end{array}$ & $\begin{array}{l}\text { Dubrovnik provides you with constant } \\
\text { beauty }\end{array}$ \\
\hline Too much if you ask me & $\begin{array}{l}\text { An airport shuttle bus brings you to the bus } \\
\text { terminus Gruž }\end{array}$ \\
\hline If you have a choice & $\begin{array}{l}\text { We bring you here our top three shops in } \\
\text { Dubrovnik to check out }\end{array}$ \\
\hline $\begin{array}{l}\text { If you like to take on road, you'll enjoy } \\
\text { winding roads }\end{array}$ & \begin{tabular}{l} 
This road will also take you through Neum \\
\hline
\end{tabular}
\end{tabular}

The above table shows in the left-hand column the pronoun you with reference to the potential tourist performing an active role, either with auxiliary or lexical verbs.. On the other hand, in the right-hand column either the destination, Dubrovnik, or an area or a means of transport, are mostly represented as taking an active role, which means that they are personified, and consequently you features an object position, that is to say it is 'acted upon'.

Furthermore, the performed analysis reveals a higher number of words related to both the natural beauty of Dubrovnik, as for example ...sea, beach, island, sunset, the Adriatic..., a fact which is not surprising for a destination boasting both - its natural beauty as well as its world famous artistic heritage and architectural features (Bait et al. $2018,8)$

Given the fact that the main purpose of promotional texts is to be descriptive, but more importantly, to be persuasive, table 5 shows the most representative evalutive lexis.

\section{Table 5: Evaluative lexis in analyzed corpus}

\begin{tabular}{|l|l|l|}
\hline Rank & Lema & Hits \\
\hline 7 & unique & 61 \\
\hline 23 & beautiful & 35 \\
\hline 42 & wonderful & 24 \\
\hline 45 & idyllic & 19 \\
\hline 48 & ancient & 17 \\
\hline
\end{tabular}

The above table shows that evaluation appears to occur in favour of adjectives connoting beauty and attractiveness of Dubrovnik on the one hand and also of adjectives with a stronger focus on the location's physical and cultural and historical characteristics on the other hand which implies the authenticity (Dann 1996: 98) of the place. 
ToSEE - Tourism in Southern and Eastern Europe, Vol. 5, pp. 121-138, 2019

B. Bosnar-Valković, S. Jurin: COMMUNICATION AND MANIPULATION STRATEGIES OF ...

\subsection{Quantitative analysis of sentiment features of travel guides}

In order to provide further insight and additional value of the results gained by qualitative text linguistic research, a quantitative analysis using Mediatoolkit (https://www.mediatoolkit.com/features) focused on the frequency and distribution of words and syntagms closely connected with Dubrovnik has been conducted. Mediatoolkit is a media monitoring tool that tracks relevant mentions across the web and social media in real time which outlines the key facts and statistics about the relevant mentions. It is in fact a powerful combination of media monitoring and intelligence.

A high frequency of the words and syntagms Dubrovnik, Dubrovnik tourism destination, Tourist destination Dubrovnik and Dubrovnik tourism destination Croatia was found out. Aimed at identifying representative sentiment features of the above mentioned words and syntagms connected with Dubrovnik, a sentiment analysis of the general feelings of the selected travel guides texts, using open source tools, was performed. Accordingly, impact of these words and syntagms on two media: Web and YouTube for the period 23.12.2018 - 23.01.2019 was analyzed.

A detailed analysis with a breakdown of the most important metrics is presented as it follows:

Analyzed period: $23.12 .2018-23.01 .2019$ 
ToSEE - Tourism in Southern and Eastern Europe, Vol. 5, pp. 121-138, 2019

B. Bosnar-Valković, S. Jurin: COMMUNICATION AND MANIPULATION STRATEGIES OF ...

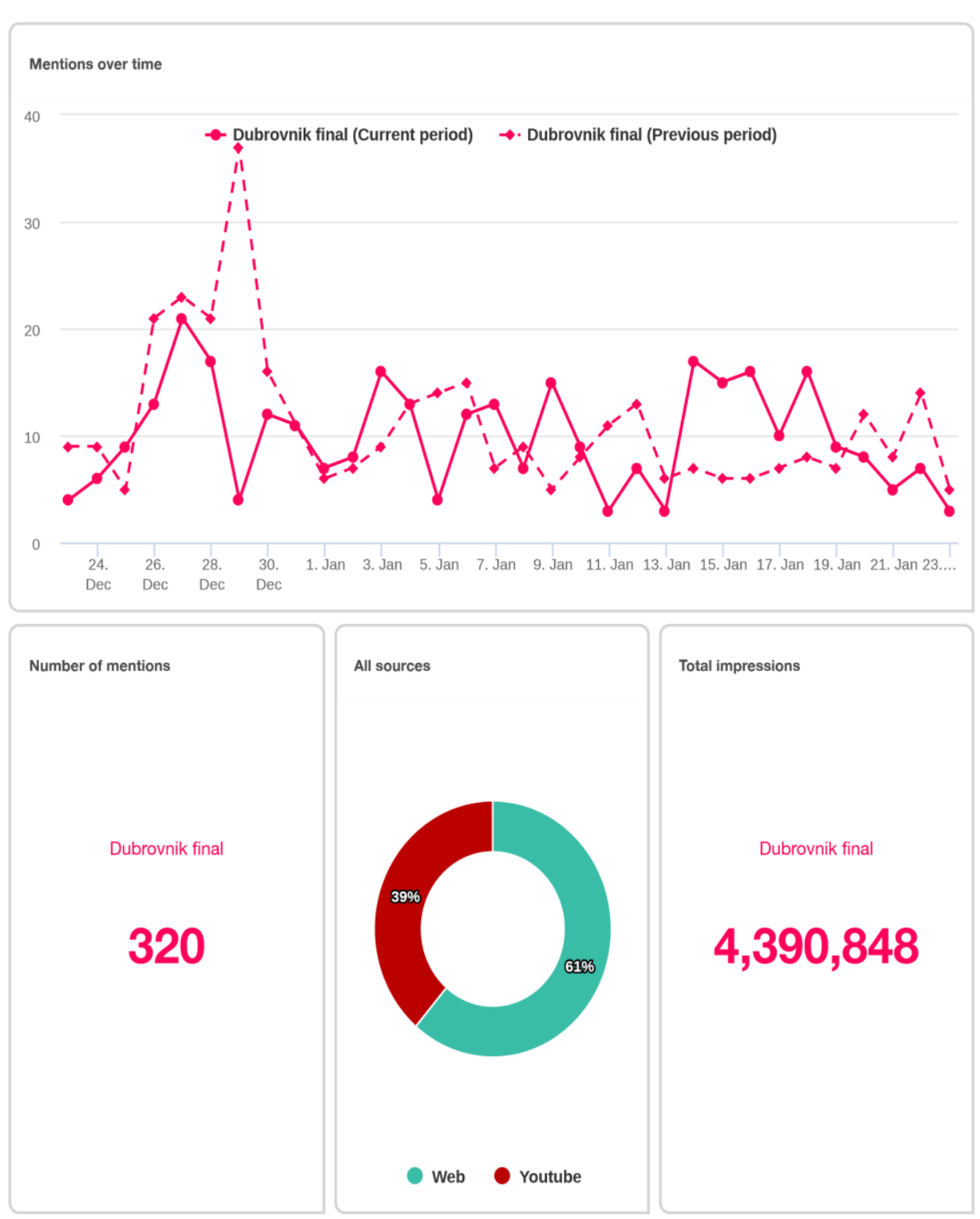


ToSEE - Tourism in Southern and Eastern Europe, Vol. 5, pp. 121-138, 2019

B. Bosnar-Valković, S. Jurin: COMMUNICATION AND MANIPULATION STRATEGIES OF ...

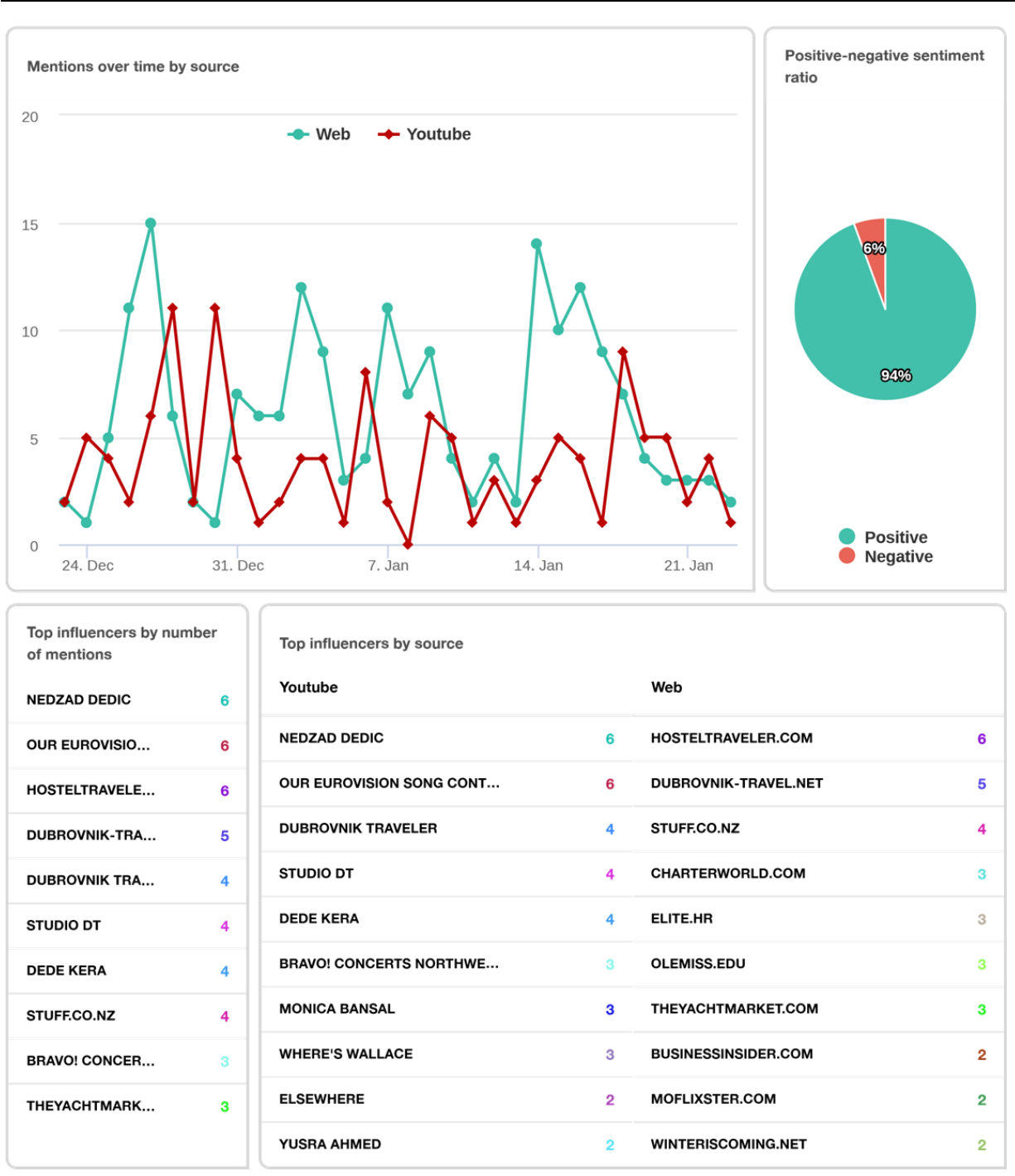


ToSEE - Tourism in Southern and Eastern Europe, Vol. 5, pp. 121-138, 2019

B. Bosnar-Valković, S. Jurin: COMMUNICATION AND MANIPULATION STRATEGIES OF ...

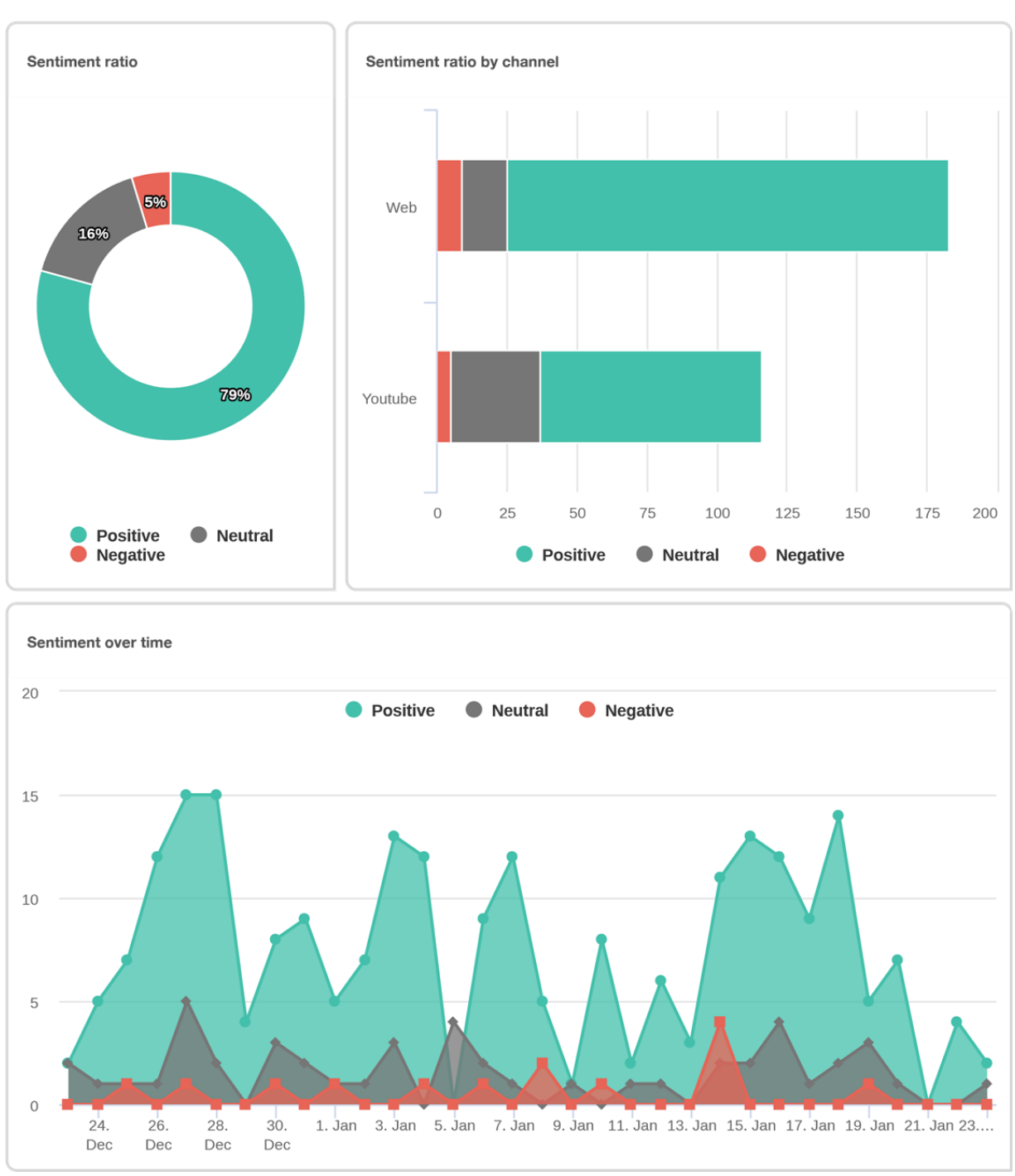

To complete our analysis, we performed a sentiment analysis (Pang and Lee, 2008; Godbole, Srinivasaiah and Skiena, 2007) on the content. To perform it, we used the online free tools consisting in three sentiment analysis engines.

These engines are cloud-based tools adopting a Natural Language Processing algorithm to perform the analysis. Following the software technical specification, the algorithms operate on the selected text through the following steps:

1. break the sentences of the document into their structural elements (e.g. nouns, adjectives, verbs, and adverbs), on the basis of the selected language;

2. identify sentiment-bearing phrases (for example "extraordinary experiences" or "a truly breathtaking place";

3. each of the identified phrases gets a logarithmic score, ranging from -10 to 10 ; 
ToSEE - Tourism in Southern and Eastern Europe, Vol. 5, pp. 121-138, 2019

B. Bosnar-Valković, S. Jurin: COMMUNICATION AND MANIPULATION STRATEGIES OF ...

4. the software combines the obtained scores and determines the overall sentiment of the text, assigning a score in the range from -2 to 2 .

The output of the sentiment analysis showed the general sentiment of the analyzed documents (positive, negative or neutral).

From the number of word mentions and syntagms like Dubrovnik, Dubrovnik tourism destination, Tourist destination Dubrovnik and Dubrovnik tourism destination Croatia which was in total 320 for that period, $61 \%$ of mentions was recorded on the Web and only $39 \%$ on You tube, which indicates that a lower percentage of children, youngsters and younger adults are referring to travel guides about Dubrovnik (the percentage of younger people using You tube is higher than the one of adults), probably caused by the price range of Dubrovnik which in general is not affordable for youngsters and younger adults. In the range of positive versus negative sentiment ratio the results show $94 \%$ of positive sentiment reactions versus $6 \%$ of negative sentiment evaluations.

The above diagram presenting the comparison performed between Web and You tube mentions over time shows that the highest frequency of 15 of words and syntagms Dubrovnik, Dubrovnik tourism destination, Tourist destination Dubrovnik and Dubrovnik tourism destination Croatia is recorded on Web and that was recorded between the 27 and 29 December, 2 days after Christmas but still 2 days before New Year's Eve, which can also be closely related to the price range, because New Year's Eve and the day after that are one of the most expensive days in the whole tourism season.

The lowest frequency ratio $(0)$ is recorded on You tube on 8 January which can be related to the official end of Christmas and New Year's celebrations and holidays. In the evaluation of sentiment ratio on Web and You tube the results show $79 \%$ of positive sentiment ratio, $16 \%$ of neutral ratio and 5\% of negative. Results on Web show 170 positive mentions, 15 neutral and 5 negative.

The most positive mention ratio on Web is shown in the period between 26 and 29 December, and the lowest negative mention ratio is shown on 21 January. In the evaluation of sentiment ratio on You tube 95 positive mentions were recorded and the most positive mention ratio was shown on 27 December accompanied by 32 neutral mentions and 3 negative mentions. Negative mentions were detected on 27 December, 4 January, 8 January, 12 January, 13 January and 21 January.

\section{MANIPULATION STRATEGIES IN ANALYZED TRAVEL GUIDES}

People have wrong perception of language as merely a means of communicating information. This is an oversimplification of the multiple purposes of a language. As Gee $(2014,1)$ states, human language serves many other functions, and the two most closely related functions would be "to support the performance of social activities and social identities and to support human affiliation within cultures, social groups, and institutions." In other words language can create social activities, values and and consequently identities. 
ToSEE - Tourism in Southern and Eastern Europe, Vol. 5, pp. 121-138, 2019

B. Bosnar-Valković, S. Jurin: COMMUNICATION AND MANIPULATION STRATEGIES OF ...

In spite of the fact that travel guides do not strictly belong to the promotional genre of tourism but rather to the informative one (they mainly provide information and descriptions), they also possess their persuasive power relying on hyperbolic language and glamorous images that can trigger interest, excitement and also suggest relaxation depending on their subtile selection of colours (Kaewnopparat 2017, 29). The power of persuasion in travel guides is based both on communicative, i.e. linguistic elements as well as on visual elements.

In this study we are focused on communicative elements of persuasion and their short analysis will prove that travel guides are not just information-driven but also a profitdriven text genre.

Persuasion is an attempt to change the attitudes or behaviour, or both without using coercion or deception (Fogg, 2003). When the motivation and ability are sufficient, with the correct triggers, visitors may change their behaviour (Fogg, 2009), or at least make up their mind to make the decision to select a suitable travel destination. The roots of persuasion theories go far into the past as Aristotle discusses the concept of rhetoric by means of ethos (appeals to credibility), logos (appeals to logic), and pathos (appeals to emotion) (Gurak, 1991 and Winn \& Beck, 2002). Aristotle defines rhetoric as "the faculty of finding the available means of persuasion" as cited in Gurak, 1991.

In this paper we refer to the well-known persuasion techniques by Cialdini (2007). Cialdini proposes six persuasion techniques, namely (1) reciprocation, (2) commitment and consistency, (3) social proof, (4) liking, (5) authority, and (6) scarcity. He explains that once persuaded, human may react automatically without conscious thought. The techniques are widely used in many fields, especially in the advertising domain. Due to the fact that tourism domain is unique, we tried to identify the remarkable persuasion techniques used in analzyed travel guides.

\subsection{Social Proof}

People are prone to imitate others and when they become uncertain, they will usually follow the others (Cialdini, 2007). Thus, providing evidence of what others do and how they do it, can serve as a social proof that it is worth to be like them, i.e. to act like them. In travel guides, providing evidence that other people had visited interesting places, can lead to persuasion. The message stating that ,there is a very long history of famous people who have visited Dubrovnik, from Richard the Lionheart, Wallis Simpson, Prince Edward, Elisabeth Taylor, Richard Burton, Michael Douglas, Catharine Zeta Jones, Goldie Hawn, Kurt Russell, Richard Gere, Nick Nolte and Tom Cruise to celebrities, famed athletes, and virtuoso musicians. Every summer the polished stone slabs in Stradun show the reflection of world-famous persons" can lead to persuasion. This technique works if the person is either someone close to the targeted customer or if it is a celebrity because people can be influenced by someone they like the most. 
ToSEE - Tourism in Southern and Eastern Europe, Vol. 5, pp. 121-138, 2019

B. Bosnar-Valković, S. Jurin: COMMUNICATION AND MANIPULATION STRATEGIES OF ...

\subsection{Liking}

Travel guides provide favourable and relevant images. Potential customers usually imagine what a destination is like using pieces of information or images that they have viewed. Once they form a solid expectation of the place, the mental images will then help them decide (Fiore, Jeoung 2007, 121). In order to assist customers to create positive mental images, a good approach is to have an attractive and informative visual design of a travel guide that can encourage customers' liking.

Tangibility is said to be one of the most significant factors of emotional design and helps to increase the level of liking and interest (Winn \& Beck, 2002, 34).

\subsection{Authority}

People tend to obey (or copy) authoritative figures, as in Cialdini, (2007). Sources of authority can be generic; it can be a leader of an organization, celebrities, or even materials such as uniform, money or food. In tourism, words of a well-known international celebrity chef being at a place with wonderful cuisines can draw much more attention than just an image of an unknown figure. On the other hand, the message that „The Japanese owners will be in the kitchen, preparing authentic sushi, sashimi, udon, crispychicken and gyoza dumplings"can get potential guests motivated to visit „Shizuku“ Japanese restaurant in Dubrovnik.

\subsection{Scarcity}

Since perceived scarcity will generate demand, it is one of the most popular techniques used in advertising. For example, saying that offers are available for a „limited time only or ,,a limited number of guests ${ }^{\text {ee }}$ can act as a trigger to act fast, which encourages sales. In the travel guide the message saying that „You must book in advance" a table at the restaurant „Nishta“ serves as a trigger to encourage awareness of scarcity.

The information „Although the shelling of Dubrovnik in 1991 horrified the world, the city has bounced back with vigour to enchant visitors again" also suggests some kind of scarcity because Dubrovnik as one of the most prominent world destinations is the only site in Europe on the Unesco's list of world heritage that was shelled and bombed (by Serbs) during the Homeland War.

Taking into account that the title of this chapter is „Manipulation strategies in analyzed travel guides" and that in this chapter the focus is on persuasion power and persuasion techniques, we can justify it in the following way: As Aristotle had defined rhetoric as "the faculty of finding the available means of persuasion", we can say that the communication in travel guides is partly based on persuasive power marked by hyperbolic language, glamorous images and persuasion techniques which from our point of view can be identified as soft or subtle manipulation. If we refer to the definitons of both verbs, to persuade - to make someone do or believe something by giving them a good reason to do it or by talking to that person and making them believe it; and to manipulate - to control or influence somebody/something, often in a dishonest way so that they do not realize it, we can state that the verbs to persuade and to manipulate cannot 
ToSEE - Tourism in Southern and Eastern Europe, Vol. 5, pp. 121-138, 2019

B. Bosnar-Valković, S. Jurin: COMMUNICATION AND MANIPULATION STRATEGIES OF

be precisely delimited because ,a good reason“ when persuading someone can also be of manipulative nature in order to make somebody believe it. On the other hand ,in a dishonest way" as a part og definition of the verb to manipulate is of a very fluid meaning when referring to the context of advertising, making profit etc. The question is in fact what is ethically allowed or not. However, nowadays in some areas of life ethical principles also undergo certain changes and adjustments, so that it is quite complex to set strong boundaries. Consequently, we can conclude that the delimitation between the acts of persuasion and manipulation is also quite fluid, and due to this fact persuasion can be equalized with ,soft“" manipulation.

\section{CONCLUSIONS AND FURTHER RESEARCH}

The above analysis can substantiate the thesis set forth in the introductory part of this research, which proposes that the text genre travel guide is used in the communication process of tourism promotion and tourism consumption and that it is both informative and persuasive.

Text linguistic analysis showed that the travel guide is prevailing an assertive text type, subtypes informative, explicative and orientative texts, and concerning its persuasive form in some text it also belongs to the directive text type, subtype instructive texts. On the macrostructural level the text genre travel guide is divided into text segments with the cohesive and coherent purpose. Also, travel guides show a multimodal theme perspective - a combination of images, text, drawings and collage is present in almost all analyzed texts of travel guides. On the language stylistic level a high frequence of time adverbs, adjectives, hyperbolizations and numerous cases of passive voice perspective was recorded. This research also detected a strong use of modalization (verbs such as should, must, need) or expressions such as certainly, surely, or likely, used to state advice, tips, epistemic certainty and epistemic probability.

The quantitative analysis showed that the analyzed texts are mainly descriptive and that the verbs that appear at the top of the frequency lists have a typically static meaning ( $i s$, are, has, can, have). Verbal selection tends to describe what Dubrovnik can offer to tourists with a special focus on its historical sites of interest (as suggested by protected, preserved and ancient), and on the other hand it encourages the tourist to take action (as suggested by the verbs look, head, notice, enjoy etc.). The texts also contain adjectives connoting beauty and attractiveness of Dubrovnik and the surrounding area as well as adjectives with a stronger focus on the location's physical and cultural and historical characteristics. The adjectives connoting natural beauty of Dubrovnik are mostly premodifying the nouns, as for example sea, beach, island, sky,sunset,view.

Within the qualitative analysis the analysis (using Mediatoolkit) focused on the frequency and distribution of words and syntagms closely connected with Dubrovnik has been conducted.

Aimed at identifying representative sentiment features of the most frequent words and syntagms connected with Dubrovnik, a sentiment analysis of the general feelings produced by the selected travel guides texts, using open source tools, was performed. 
ToSEE - Tourism in Southern and Eastern Europe, Vol. 5, pp. 121-138, 2019

B. Bosnar-Valković, S. Jurin: COMMUNICATION AND MANIPULATION STRATEGIES OF

The analysis of the impact of the mentioned words and syntagms on two media: Web and YouTube for the period 23.12.2018 - 23.01.2019 showed that the sentiment features are under a strong influence of the time period and the target group of guests, i.e. their age. In other words, the time period and the target group of guests are decisive factors in choosing Dubrovnik in terms of affordability as a prerequisite for arousing positive sentiments. Consequently, the analysis of sentiment features showed that in the range of positive versus negative sentiment ratio, the results are more than $95 \%$ in favour of positive sentiment reactions towards words and syntagms concerning Dubrovnik as a tourism destination, versus $6 \%$ of negative ratio of sentiment evaluation.

In the texts on Dubrovnik with persuasive power four out of six persuasion techniques proposed by Cialdini were registered: social proof, liking, authority and scarcity. The analysis of the four applied persuasion techniques in travel guides on Dubrovnik has led us to the conclusion that persuasion and persuasion techniques can be equalized with „soft" manipulation because there does not exist a strong delimitation between them

Our research might be further completed by including the impact of photography on travel guidess (Mogilner, Aaker, Kamvar, 2012) in order to interpret how happiness affects choice.

Overall, the obtained results based on a complex analysis including the text linguistic,quantitative and sentiment analysis present a valuable contribution and basis for further research aimed at creating texts presenting a destination that generates positive sentiments as an important prerequisite in making a final decision on visiting a certain destination.

\section{REFERENCES}

Armstrong, J.S. (2010), Persuasive Advertising: Evidence-based Principles, Palgrave Macmillan, Basingstoke. Bait, M., Jurin, S., Bosnar-Valković, B., (2018), "Croatia as a virtual tourist destination: a linguistic and sentiment analysis", Tourism and Hospitality Industry 2018, 24th International Congress, pp. 1-18, (https://thi.fthm.hr/congress-proceedings/send/5-2018/96-croatia-as-a-virtual-tourist-destinationa-linguistic-and-sentiment-analysis)

Brinker, K., Cölfen \& H., Pappert, S. (2014), Linguistische Textanalyse. Eine Einführung in Grundbegriffe und Methoden, 4. Aufl. Erich Schmidt Verlag GmbH \& Co., Berlin.

Caru, A. \& Cova, B. (2006), "How to facilitate immersion in a consumption experience: Appropriation operations and service elements", In: Consumer Behaviour, Vol. 5, Iss. 1, John Wiley \& Sons Ltd. pp. 4-14.

Cialdini, R.B., (2007), Influence: the psychology of persuasion, Collins, New York.

Dann, G. (2012), "Remodelling a changing language of tourism: from monologue to dialogue and trialogue", In: Pasos, Revista de Turismo e Patrimonio Cultural, Vol. 10, No. 4. Special Issue, Finnmark University College, pp. 59-70.

H., Fiore, A.M. \& Jeoung, M. (2007), "Measuring experience economy concepts: tourism applications", Journal of Travel Research, Vol. 46, No. 2, pp. 119-132

Fogg, B.J. (2003), Persuasive Technology: Using Computers to Change What We Think and Do, Morgan Kaufmann Publishers.

Fogg, B.J. (2009), “A behavior model for persuasive design”, Paper presented at the Proceedings of the 4th International Conference on Persuasive Technology, Claremont, California, pp. 1-7.

Gold, J.R. (1994), "Locating the Message: place promotion as image communication", In: J.R. Gold and S.V. Ward, eds. Place Promotion: the use of publicity and public relation to sell towns and regions, Chichester, John Wiley, pp. 19-37. 
ToSEE - Tourism in Southern and Eastern Europe, Vol. 5, pp. 121-138, 2019

B. Bosnar-Valković, S. Jurin: COMMUNICATION AND MANIPULATION STRATEGIES OF ...

Godbole, N., Srinivasaiah, M. and Skiena, S. (2007), "Large-Scale Sentiment Analysis for News and Blogs", ICWSM, 7, 21.

Gurak, L.J. (1991), "Evaluating the use of metaphor in software interface design: a rhetorical approach", Paper presented at the Professional Communication Conference, IPCC '91. Proceedings, 30 Oct. - 1 Nov., The Engineered Communication, International, pp. 267-271.

Heinemann, M.\& Heinemann, W. (2002), Grundlagen der Textlinguistik, Niermeyer, Tübingen.

Heinemann, W.\& Viehweger, D. (1991), Textlinguistik. Eine Einführung, Niemeyer, Tübingen.

Hoffmann, L. (1998), "Fachtextsorten: Eine Konzeption für die fachbezogene Fremdsprachenausbildung", In: L. Hoffmann, H. Kahlverkämper \& E. Wiegand (Eds.), Fachsprachen. Ein Internationales Handbuch zur Fachsprachenforschung und Terminologiewissenschaft, 1.Halbband. Walter de Gruyter, Berlin, New York. pp.468-482.

Holloway, J.C. (2004), Marketing for Tourism, Prentice Hall, 4th ed.

Ivanetić, N. (2003), Uporabni tekstovi, Zavod za lingvistiku FF, Zagreb.

Jee, J.P. (2004), Discourse analysis theory and method, Routledge, 2nd ed.

Jurin, S., Krišković, A. (2017), Texts and their usage through text linguistic and cognitive linguistic analysis, Faculty of Humanities and Social Sciences, Rijeka.

Kaewnopparat, J. (2017), The Impact of Photography on Tourism: Photography Construction Perspective, Doctoral dissertation, University of Tennessee, Knoxville.

Lee, W. \& Gretzel, U. (2012), "Designing persuasive destination websites: A mental imagery processing perspective", Tourism Management, Vol. 33, No. 5, pp. 1270-1280 doi: 10.1016/j.tourman.2011.10.012.

Leeuwen, van, T. (2005), Introducing Social Semiotics: An Introductory Textbook, Routledge.

Matheson, D. (2005), Media Discourses: Analysing Media Texts, Open University Press, New York.

Mogilner, C., Aaker, J., \& Kamvar, S.D. (2012), "How happiness affects choice", Journal of Consumer Research, Vol. 39, No. 2, pp. 429-443.

Nasukawa, T. \& Yi, J. (2003), "Sentiment analysis: Capturing favorability using natural language processing", Proceedings of the 2nd international conference on Knowledge capture, ACM, pp. 70-77.

Nilsson, T. (2001), Noun Phrases in British Travel Texts : a corpus-based study, Uppsala Universitet.

Pang, B. \& Lee, L. (2008), "Opinion mining and sentiment analysis", Foundations and trends in information retrieval, Vol 2, No. 1-2, pp. 1-135.

Winn, W. \& Beck, K. (2002), "The Persuasive Power of Design Elements on an E-Commerce Web Site", Technical Communication, Vol. 49, No. 1, pp. 17-35.

Yui Ling Ip, (2008), “Analyzing Tourism Discourse. A Case Study of a Hong Kong Travel Brochure”, In: LCOM Papers 1, pp. 1-19.

Travel guides:

Lonely Planet Travel Guide Croatia, Lonely Planet Global Limited, Dublin, $9^{\text {th }}$ revised edition.

Eyewitness Travel Guide Croatia, Dorling Kindersley Ltd., London, $2^{\text {nd }}$ edition.

Brigita Bosnar-Valković, PhD, Assistant Professor

University or Rijeka

Faculty of Tourism and Hospitality Management

Department of Foreign Languages in Business

Primorska 42, 51410 Opatija, Croatia

Phone: +385-51-294188

E-mail: bbosval@fthm.hr

Suzana Jurin, $\mathrm{PhD}$, Associate Professor

University or Rijeka

Faculty of Humanities and Social Sciences

Department of German Language and Literature

Sveučilišna avenija 4, 51000 Rijeka, Croatia

Phone: +385-51-265619

E-mail: sjurin@ffri.hr 